\title{
Ukraine: Current Tendencies in Inclusion
}

\author{
Tamara Bondar* \\ Department of Higher Education Pedagogy and Educational Management, Bohdan Khmelnytsky Cherkasy National University, \\ Cherkasy, Ukraine \\ *Corresponding author: tamara_bondar@yahoo.com
}

Received September 21, 2014; Revised October 30, 2014; Accepted December 14, 2014

\begin{abstract}
The article discusses the legislature in Ukraine that shaped the 'inclusion' trend to provide the disabled children and youth with equal access to education. The article focuses on secondary education system that helps understand the educational setting. It gives an overview of the terms referring to the special needs children. Areas of particular concern include the inclusion of the disabled youth in higher education that is currently lacking the concept. It examines the reasons that hinder 'inclusion' and measures to be taken to improve the situation.
\end{abstract}

Keywords: children with special needs, disabled, legislature, secondary and higher education

Cite This Article: Tamara Bondar, "Ukraine: Current Tendencies in Inclusion." American Journal of Educational Research, vol. 2, no. 12B (2014): 22-27. doi: 10.12691/education-2-12B-5.

\section{Introduction}

Ukraine, a country in Eastern Europe after gaining its independence from the Soviet Union in 1991, had to cope with multiple tasks to overcome economic and social instability. Public education faced the same difficulties that the country had to go through. Social inequality and economic stagnation affected the development in public schools. In this period European community was developing the international standards for the rights of the children that developed over the course of years and were reflected in many international documents. As Ukraine entered the $1990 \mathrm{~s}$ the country faced many challenges in safeguarding children's rights to education and providing quality education to children with special needs. Such was the context when Ukraine ratified UN Convention on the Rights of the Child adopted by the UN General Assembly in 1989. By signing the Convention in 1991 Ukraine acknowledged that children are an especially vulnerable group in view of their age, mental and physical development, and therefore they require special care and protection. By ratifying the UN Convention Ukraine committed to be legally bound by its principles and start reforming the national legislation to bring it in line with the international standards. This article discusses how Ukraine's government pursued the UN policy of protecting children's' rights, especially the rights of disabled children by developing necessary legislature, and presents some of the pressing issues that hampered the process to make inclusion a reality for Ukraine's young people and citizens with special needs.

\section{Implementation of Inclusion}

Education. The principal levels of education offered in Ukraine are: preschool level, primary general education (I level), basic general secondary education (II level), complete general secondary education (III level), vocational technical education, education qualification levels for qualified workers, basic higher education, complete higher education including graduate, postgraduate and doctoral education, and self-education [1]. The general (regular) secondary school of I-III levels comprises primary general school - I level, basic general school - II level, high school - III level. There are the types of the general secondary schools including: specialized general school (boarding school) of I-III levels for gifted children that provides intensive learning programs in selected subjects and courses in addition to general education standard; "gymnasium" of II-III levels that provides intensive learning programs in the subjects of specialization emphasized by a particular school; lyceum of III level that provides specialized track education and prevocational training; collegium of III level that provides general education in the area of philological-philosophical and cultural-aesthetic tracks.

For many years, children with developmental problems, sensory disorders, brain dysfunction and complex disorders have remained at the margins of the Ukrainian secondary education system or have been totally excluded from it. These children were educated by a separate, special school system which consists of independent institutions, many of them operating as boarding schools for children who lived too far from the school to commute each day [2]. The variety of boarding schools includes: general boarding school that provides fully or partly for the children that need social care; special general school (boarding school) is for children who need correction of mental and/or physical development (this term is used in General Education Act); general education sanatorium school (boarding school) of I-III levels with impairment specialization is for children who need long term treatment; social rehabilitation school (boarding school) is for children who are in need of 'special education'(gender 
separate); evening school of I-III levels is for those who are not able to study in the general school. The Ministry of Education and Science of Ukraine supervises both general schools and some special schools. According to its statistics there are 396 special secondary schools with 54,100 children, 40 educational rehabilitation centers for children with mental or physical disorders, 142 special preschool institutions and 1200 special education groups in mainstream preschools with 45,000 preschoolers [3]. Although new standards have been adopted, special education remains primarily segregated from general education in contrast to western trends.

The Ministry of Labor and Social Policy supervises 298 rehabilitation centers where 208 institutions are early rehabilitation centers for children with developmental disorders and 90 are centers are for medical, social and professional rehabilitation. There is a group of special centers that fall within the scope of the Ministry of Health of Ukraine. Each ministry pursues its own goal. The Ministry of Education and Science offers educational and correction services. The Ministry of Labor and Social Policy pursues social care and renders support and social assistance. The Ministry of Health focuses on health care issues. Such differentiation in responsibilities is some sort of historical heritage Ukraine received from the Soviet system where general and special education was separated. Traditionally mainstream schools transferred their problems to special schools that developed in isolation.

The population of the children with disabilities was growing and the conditions in special schools were worsening with every year caused by the insufficient government funding. Children were put in special institutions often without their parents' consent. In many cases parents had to go through much pressure from state officials if they rejected the special institution services. Those who decided to raise a disabled child at home experienced financial difficulties that led to inadequate provision of the disabled child's needs. Because of the international agreements and conventions on human rights, the situation is slowly changing. Special education, social protection of children with disabilities, integration and inclusion of the disabled children in general and special education are slowly gaining some national attention.

Terminology. Although Ukraine developed its legislature in alignments with the UN Convention on the Rights of the Child where the term 'disabled child' was used, the term 'child-invalid' was common for most legislature through 2012 reflecting the medical model when discussing the issues of the children with special needs. The changes in terms show the evolution in the legislature and changes in the society awareness of the problem. The terms that were used in acts, decrees, orders, and regulations by year include: 1991 - 'child-invalid', 'children with hearing impairments', 'children with physical or mental developmental impairments, 1993 'children with language impairments', 1996 - children with sensory disorders, 'child-invalid', 'children with physical or mental developmental impairments', 1996 'children who need correction of mental or physical development', 1999 - 'children with special needs', 2000 - children-invalids', 'children with physical or mental developmental impairments', 2001 2002 - 'children with limited abilities', 'children-invalids', 'children with physical or mental developmental impairments', 2003 - 'children who need correction of mental or physical development', 'people with limited abilities', 'people in difficult conditions', 2004 - 'children who need correction of mental or physical development', 'children with sensory disabilities such as visual impairment or blindness and deafness or hearing impairments', 'children with mental retardation', 'children with severe language disorders', 'pupils with special educational needs', 2005 - 'children with limited abilities', 'children-invalids', 2006 - 'persons with invalidity', 'persons who need correction of mental or physical development', 'persons with special educational needs', 'children with limited abilities', 2006 - 'children-invalids', 'children with limited functional abilities', 'children who need social and psychological correction, 2007 - 'children with limited physical abilities', ‘children-invalids', 2008 - 'children-invalids', 'persons who need correction of mental or physical development', 'children with limited physical abilities', 2009 - 'persons with special educational needs', 'children who need correction of mental or physical development', 'pupils with developmental disorders', 'children-invalids', 2010 'children with special educational needs', 'children with limited physical abilities', 2011 - 'children with special educational needs' and all medial categories, 2012 'children with special educational needs' and all medial categories, 2013 - 'children with invalidity', 'persons with invalidly', 'children with limited physical abilities', 'children with special educational needs', 'children with special needs', 'children-invalids', and medical categories, 2014 - 'persons with special educational needs' is first defined in "Higher Education Act" (passed July, 1, 2014) [4] as a person with invalidity who needs additional support to be able to receive higher education.

The variety of terms can prove the confusion among politicians and misunderstanding of the 'inclusion' issue by the government. It can also show the dynamics of how Ukraine has been struggling to conform to European norms and values [5]. Lack of definitions caused messed rhetoric. Insufficient research into the 'inclusion' issue made acts inactive.

Legislature and Inclusion. Moving forward in providing disabled students with equal access to education the Supreme Rada (the legislative branch of the Ukrainian government) passed the laws to align the Ukrainian legislature with the European standards. The right to education is guaranteed by the Constitution of Ukraine. Article 53 of the Constitution recognizes the right of everyone to education and defines complete secondary education as compulsory. The first national law adopted after Ukraine ratified the UN Convention on the Rights of the Child was Invalids Social Security Basics Act (875-12 issued March 1991) [6].

Between 1991 and 2000 education and practical guarantees of children's rights were governed by the laws of Ukraine Education Act (1991), President's Decree on the National Program 'Children of Ukraine' (1996), the Concept on State Special Education for Children with Special Needs (1999), General Secondary Education Act (1999). The National Program refers to the UN Convention on the Right of the Child and declares the early rehabilitation of the disabled children to be the national priority. As the Program stated $60 \%$ of children that start elementary school are with disabilities. $10 \%$ of 
elementary students have learning difficulties. This is the first national document that used the term "integrated". It stated that '....segregated special education in the boarding houses should be replaced by integrated education' [7]. In 1999 the Ministry of Education of Ukraine and Presidium of Pedagogical Sciences Academy signed the Concept on Special Education State Standards for Children with Special Needs that was meant to reform the special education content [8]. Although the Concept uses the term 'children with special needs', it is limited to disabilities. Children with special needs are qualified as children with visual impairments, hearing problems, severe speech disorders, mentally retarded children, children with disorders in mental development, children with cerebral palsy placed in special setting. Whereas the Framework for Action on Special Needs Education states that special needs children 'include disabled and gifted children, street and working children, children from remote or nomadic populations, children from linguistic, ethnic or cultural minorities and children from other disadvantaged or marginalized areas or groups. In the context of the Framework, the term 'special educational needs' refers to all those children and youth whose needs arise from disabilities or learning difficulties when placed in inclusive setting [9].

The Concept admitted that the special schools were insufficient in providing services to the children with special needs because it was guided by the Sate general education standards. It stated that the efficiency could be improved by complete replacing the existing organization techniques, curricula, teaching methods, and instructional content to meet the special needs of the children with disabilities. This direction contradicted the Framework statement that did require the curricula to be adapted to children's needs. Children with special needs should receive additional instructional support in the regular curriculum context, not a different curriculum. The guiding principle should be to provide all children with the same education, providing additional assistance and support to children requiring it [10].

The Concept didn't exclude the opportunities for the children to study at the general school or special unit or class in the general school, implying that those will be the rare cases. The Concept overlooked the main statement given in the Salamanca Framework that the assignment of children to special classes or sections within a school on a permanent basis should be the exception, to be recommended only in those infrequent cases where it is clearly demonstrated that education in a regular classroom is incapable of meeting child's educational or social needs or when it is required for the fare of the child or of the other children [11].

There were no provisions for making special schools valuable resource for the development of inclusive education or servicing as training and resources centers for staff in regular schools. It did not state either that special schools or units within inclusive schools may continue to provide the most suitable education for the relatively small number of children with disabilities who can't be adequately served in regular classrooms or schools.

The General Education Act of 1999 made the major change in assigning pupils to the special schools. In the well-established system of special institutions medical boards were responsible for assigning children with special needs in schools with specific impairments. Now though parents received the right to disagree with the medical-pedagogical board verdict and reject sending their child to a special institution and provide individual schooling at home. That was the only option stated by the Act at that period [12].

The end of 2000 was marked by two important regulations aimed at rehabilitation and equalization of opportunities and social integration of all people with disabilities. The Cabinet of Ministers Ruling №1545 of October 10, 2000 approved the Concept of ChildrenInvalids Early Rehabilitation. It worded the statement given in the 1996 President's Decree that '...segregated special education in the boarding houses should be replaced by integrated education [13].

The State Social Welfare for Children Invalids Act 2109-III of November 2000 forbade discrimination against the disabled children. It provided financial support to families with disabled children and insisted on removing the architectural barriers to provide equal access to full participation in social life and take fuller account of the different needs of children [14].

Between 2001 and 2010 there were adopted about 40 different laws, decrees, and regulations aimed at developing inclusive education. The Pre-School Education Act, Extracurricular Education Act, Vocational Training Act, Higher Education Act, National Education Development Doctrine were intended to recognize the principle of equal opportunities for all children, youth and adults with disabilities in primary, secondary, and tertiary education carried out in integrated setting.

In July 2005 the President's Decree on urgent measures to provide for the ongoing development of education in Ukraine (N 1013/2005) was passed. Three months later in October 2005 the Supreme Rada passed the Invalids Rehabilitation in Ukraine Act. In terms of clarity, that was the first law to have identified about 30 terms relating to rehabilitation services, education, medical support, and social provision. However, the definitions of the terms 'invalids', ‘children-invalids', ‘invalidity' 'functional limitations' were added to this law only in 2011. The regulation states (2011) that 'a child-invalid is a person until 18 years old, with constant functional disorder which causes some functional limitations when interacting with the environment, therefore requires the government to provide for necessary conditions to ensure that children realize full potential, enjoy equal rights and are socially protected [15].

However, the act that inspired legislative measures in the sphere of inclusive education was adopted in 2009. It was the National Program 'The National Action Plan to Realize the UN Convention on the Right of the Child' through 2016 Act (№ 1065-17 of March 2009). Before it was adopted and came into force it had been under discussion in the Supreme Rada for three years. The Preamble to the Act states that the National program is aimed at wider changes and coordination of many institutions to improve the quality and access to education for all children. The law did not use the tern 'inclusive schooling in general schools'. However, by stating that all disabled children will have been provided with psychological, social pedagogical, medical, and judicial, information services to meet their special needs by 2016, the law implies full inclusion [16]. 
The law (N 1065-17) was followed by the Ministry of Education and Science Order N 855 to approve the Ministry's Action Plan to realize the inclusive schooling in general secondary schools between 2009 and 2012 [17], and Cabinet of Ministers Regulation (N 1263-p) on Action Plan for the 2010 State Program 'National Action Plan to Realize the UN Convention on the Rights of the Child through 2016' to approve measures to realize the program in 2010 [18] in which the term 'inclusive' was first used. It stated that the inclusive schooling should be introduced in the general school setting.

The legislative efforts resulted in the Concept of Inclusive Schooling (№ 912 of October 10, 2010) approved by the Ministry of Education and Science [19].

In terms of legislative advancements to develop inclusive education the period between 2011 and 2014 was very intensive. There have been about 20 different regulations referring to the inclusive schooling in general school setting in terms of organizational issues, curricula, assessment, loads, psychological support provision, pedagogy, and new staff to assist the general teacher with inclusive schooling. The Supreme Rada introduced some changes into the General Secondary Education Act (1999) adding that 'general schools can have special and inclusive units for disabled children'. Exclusion deeply rooted in the country's historic context, started slowly giving way inclusion tendencies after almost twenty years.

The Ukrainian Parliament Commissioner for Human Rights Mrs. N. Karpachova emphasized in the special report on the occasion of the 20th anniversary of ratification by Ukraine of the United Nations Convention on the Rights of the Child that on January 1, 2010, there were 157,474 children with special needs in Ukraine. Most of them suffer from nervous system pathologies, mental and behavioural aberrations, as well as congenital development defects. More than 23,000 Ukrainian children suffer from cerebral palsy. Protection of disabled children's rights requires improvement of their material status, as well as special conditions for their integration into social life [[20], p. 126]

Higher Education and Inclusion.

Dr. K. Kolchenko, President Adviser for Inclusion at Open International University of Human Development 'Ukraine' considers that 'the present stage of integration of students with disabilities in higher education of Ukraine started only in 1999 when the University 'Ukraine' was founded. It is the first university in Ukraine that admitted students with disabilities. The university branches (affiliates) were opened in 20 cities throughout Ukraine that year that provided educational services for the students with low mobility and income. The mission of the university is to provide equal access to education for people with special needs [21].

In 2002-2003 there were about 1,000 disabled students at the university and 8,000 disabled students countrywide who came from special "segregated' schools or from homes being excluded from society. By analyzing the legislature at that period we can conclude that the government considered the restricted environment to be the main reason that hindered the inclusion of the disabled students, because of the President's Decree of June 2005. Among the priority measures to be taken to provide the conditions for the disabled persons was to build ramps in all educational institutions and to introduce relevant courses at Construction departments [22]. Although the plan was well developed, it was impossible to realize because of the constrained deadlines and lack of funding. Among other priorities that needed to be addressed were assessment as to what students with disabilities would need to fully participate in an educational program, provision for the disability support, professional care staff, accommodation adapted to the needs of students with disabilities, support with day-to-day living. It resulted in difficulties that faculty and disabled students experienced in the classroom. "The notion of systematically providing accommodations for university students with disabilities is foreign to most instructors in Ukrainian colleges and universities. Instructors tend to be at a loss as to how to facilitate learning and evaluate students with disabilities. Some immediately assume that students with visible disabilities such as cerebral palsy or blindness will not be able to manage the academic demands of higher education [23]. The government lacked the Concept of how to include the disabled students in higher education and accommodate them, satisfying their special needs.

The Ukrainian model of inclusive higher education was first developed at Open International University of Human Development UKRAINE. Its mission, objectives and directions were explained in 'The Concept of inclusive education for the disabled students' and published on the university site and some scholarly publications. BESO volunteer professors Peter Mittler from Manchester University and Joahim Klaus from Karlsruhe University (Germany) assisted the university faculty in developing this document. There is no National Concept for the inclusive higher education in Ukraine that would ensure continuous educational services to the disabled people. Thus, the experience accumulated at the University could serve as the foundation to design the National Concept for the inclusive education in universities in Ukraine to provide inclusive setting for students with special needs. The greatest concern that the university faculty express about their disabled graduates' future is that society is not prepared to accept qualified disabled people as equals; their needs are ignored; and they are again excluded [24].

Inclusion Stakeholders. Inclusion in Ukraine has been driven by movements for civil rights from outside international forces. The legislative documents refer to international acts such as Standard Rules on the Equalization of Opportunities for Persons with Disabilities, UN Declaration of the Rights of the Child, Salamanca Statement and Framework for Action on Special Needs Education, UN Declaration of the Rights of Persons with disabilities.

Non governmental organizations, including parents associations are key factors in promoting changes in Ukrainian society. They are considered to have initiated the inclusive education discussion to focus on disabled and homeless children. The most effective work in inclusion today is being accomplished by the Ukrainian Step by Step Foundation, a non-governmental, non-profit organization that aims at promoting democratic reforms in education.

The foundation fosters quality education for all children, especially children with special needs, children of national minorities, children from socially unprotected families or homeless children. Since being launched in 1999, the project implemented demonstration integration programs 
in 17 regions, reaching more than 15,510 children and their families. The project attempted to reform Ukraine's educational system through 3 programs: teacher training, inclusion, and educating minorities [25].

The International Renaissance Foundation (IRF) accomplished two projects "Disabled children rights to quality education” (2005 - 2006), and "Implementation of inclusive education in Ukraine (2007). Ukrainian Step by Step foundation jointly with the International Step by Step Association (NL) and the Every Child organization (UK) and with support of the Institution Building Partnership program of the TACIS launched a project "Creating centers of Excellence for Inclusive Education of Children with disabilities in mainstream schools” (2003 - 2004). TACIS carried out a project "Civic education in Ukraine” (part of this project is teaching children with special needs for civic education) (2004 - 2007). CIDA projects on inclusion for disabled and homeless children (2005 - 2007) attempted to promote inclusive philosophy [26].

Because of the NGO active involvement the term "children with special needs" replaced the terms with negative meaning like 'children with limited abilities', 'children with disorders in development' in recent documents [27].

Due to the National Assembly of Disabled People of Ukraine and the Ombudsman, Ukraine signed the UN Convention on the Rights of Persons with Disabilities and its Optional Protocol on September 24, 2008 and ratified it on December 16, 2009. Parliamentary ratification of those international documents have established a sound legal ground for more effective and fair protection of the rights of people with special needs, for instance, disabled children [28]. The reality was different. In 2007-2008 50,300 children who needed correction of their physical or mental development studied in 387 special educational institutions. However, only 6,100 of those children studied in specialized classes in general schools. The Ombudsman was convinced that Ukraine didn't yet establish a proper environment for integration of disabled children in the general education system. Besides, special methodologies and teaching aids should be developed to improve teaching for students of the boarding schools under the Ministry of Labor and Social Policy of Ukraine [29].

The Ombudsman believed that special programs and material resources should provide the setting to realize the constitutional right to education for talented young people with special needs. This is particularly relevant for their vocational and university education. Given that more than $2 \%$ of children are disabled, they constitute only $1 \%$ of the total number of students of vocational schools and less than $0.5 \%$ of university students. Most disabled people who are physically able and mentally capable of attending higher educational institutions can't do that because of the lack of such facilities as ramps. Only a few instructors have been trained to work with children with special needs. Inability to get higher education makes prestigious work unreachable for the disabled people, too. The Commissioner paid special attention to make sure that all institutions and public authorities establish appropriate conditions for the disabled people and particularly children, and that the latter feel no obstacles or disadvantages. Barrier-free environment should become the norm of life in Ukraine. The Ombudsperson implied that the standard reference to a lack of funds for this purpose was groundless as the government expenditures on office renovation and equipment exceeded the costs of threshold-free environment by far. By 2010 only a few public institutions and cultural centers were accessible for the disabled people [30].

Researchers identified different barriers that challenge the implementation of inclusion in Ukraine including policy, funding, public attitudes, and instructional methodology. S. Phillips reported the policy to be ineffective due to the many disconnects between state rhetoric and state action [31]. A. Kolupayeva argues that only an economically stable and developed country can afford to mainstream the majority of it children with special needs [32]. S. Raver thinks that the laws alone will not change the public attitudes. It may take years and generations for people to transform and reform [33]. Implementation of inclusive education requires mandatory primary, secondary, and higher education teacher training, control of class size, availability of appropriate materials, and the presence of additional adults in the classroom to offer more individualization. It also requires educational methods that are culturally-appropriate and empiricallybased. [34]. Further, differentiated curriculum will need to be developed, written and implemented which can be a slow process [35].

\section{Conclusion}

In summary, although Ukraine makes effort to conform to European disabilities law, the mechanisms to implement and enforce this law are largely ineffective. To reform the special education system and make inclusion reality the law has to be economically justified and have community support. Further, it is necessary to coordinate Ministries to pursue the national policy and involve other interested groups that can render assistance in removing the barriers to inclusion. Effective implementation of every inclusion 'step' requires consistent data collection regarding legislative policy, funding, public attitudes, social assistance, health care issues, and ways towards merge of general and special education. The data collected will ensure the continuous movement towards inclusion. By ongoing effort to make the educational system accessible to all, Ukraine will reform society, making it more inclusive and humane.

\section{References}

[1] Korsak, K. (1998.) Evolution of continuous education in Ukraine (1990-1998). International Personnel Academy, National University/Kyiv-Mohyla Academy. Retrieved July 5, 2006, from http://eucen.org/conferences/past/Warsaw1998/ukraina

[2] Csanyi, Y. (2004). Experience of transforming education provision for children with disabilities in central European countries, ELTE University, Budapest European Committee, Ministry of Children and Youth and Sports, Ministry of Education Report. [Online] Available: http://www.opensocietyfoundations.org

[3] Open Society Institute and Soros Foundations Network (2006). Educational policy toward inclusion: International Experience and Ukrainian Perspectives. [Online] Available: http://soros.org

[4] Education Act of July 7, 2014 No 1556-VII, Golos Ukraiyny, 148 (5898), August 6, 2014.

[5] Benardo, L., \& Silber, L., "Ukraine’s dream is not dead-yet,” The Globe and Mail, October 6, 2005 
[6] Invalids Social Security Basics, Act, No 875-12, March 1991, Vidomosty Verhovnoyi Rady, 21, 1991, 252.

[7] "The National Program 'Children of Ukraine'," President's Decree, No.63/96, January, 1996.

[8] The Concept on Special Education State Standards for Children with Special Needs, Ministry of Education of Ukraine, Presidium of Pedagogical Sciences Academy, No 7-5/7, 1999.

[9] "The Salamanca Statement and Framework for Action on Special Needs Education,” World Conference on Special Needs Education: Access and Quality. Salamanca, Spain, 7-10 June 1994.

[10] Ibid.

[11] Ibid.

[12] “The General Education, Act, No 5460-17, May 1999," Vidomosty Verhovnoyi Rady Ukraiyiny, 28, 230, 1999.

[13] “The Concept of Children-Invalids Early Rehabilitation," Cabinet of Ministers Ruling, 1545, October 2000.

[14] "The State Social Welfare for Children Invalids Act. No. 2109-III November, 2000," Vidomosty Verhovnoyi Rady Ukraiyiny, 1, 2, 2001.

[15] "The Invalids Rehabilitation in Ukraine Act No 2961-1V, October 2005,” Vidomosty Verhovnoyi Rady Ukraiyiny, 2-3, 36, 2006.

[16] "National Action Plan to Realize the UN Convention on the Rights of the Child through 2016' Act No 1065-17, March 2009," Vidomosty Verhovnoyi Rady Ukraiyiny, 29, 395, 2009.

[17] "Action Plan to realize the inclusive schooling in general secondary schools between 2009 and 2012," Ministry of Education and Science of Ukraine Order N 855, September 11, 2009.

[18] “Action Plan for the 2010 State Program 'National Action Plan to Realize the UN Convention on the Rights of the Child through 2016'," Cabinet of Ministers Ruling N 1263-p, 2009.

[19] "The Concept of Inclusive Schooling," Ministry of Education and Science of Ukraine Order N 912, October 10, 2010.

[20] Karpachova, N., State of Observance and Protection of the Rights of the Child in Ukraine. Special Report of the Ukrainian Parliament Commissioner for Human Rights. On the occasion of the 20th anniversary of ratification by Ukraine of the United Nations Convention on the Rights of the Child, Kyiv, 2010, 216.

[21] Kolchenko, K., Nikulina, G., "Conceptual approaches to implementation of inclusive education in higher educational institutionsux закладах," Aktualny problemy navchannia ta vukhovannia liudey z osoblyvymy potrebamy, Kyiv, Univeristy UKRAINE, 10 (12), 12-22, 2013.
[22] "Urgent measures to meet the needs of people with limited physical abilities," President of Ukraine Decree, N 900/2005, June 2005.

[23] Raver, S. A., "The Emergence of Inclusion for Students with Disabilities in Ukraine,” International Journal of Special Education, 22 (1), 32-38, 2007.

[24] Kolchenko, K., Nikulina, G., "Conceptual approaches to implementation of inclusive education in higher educational institutions," Aktualny problemy navchannia ta vukhovannia liudey z osoblyvymy potrebamy, Univeristy UKRAINE, Kyiv, 10 (12), 12-22, 2013.

[25] Raver, S. A., "The Emergence of Inclusion for Students with Disabilities in Ukraine,” International Journal of Special Education, 22 (1), 32-38, 2007.

[26] Ivanyuk, I. "UKRAINE: Regional Preparatory Workshop on Inclusive Education," Eastern and South Eastern Europe (Sinaia, Romania, 14-16 June 2007), UNESCO International Bureau of Education.

[27] Ibid.

[28] Karpachova, N., State of Observance and Protection of the Rights of the Child in Ukraine. Special Report of the Ukrainian Parliament Commissioner for Human Rights. On the occasion of the 20th anniversary of ratification by Ukraine of the United Nations Convention on the Rights of the Child, Kyiv, 216, 2010.

[29] Ibid.

[30] Ibid.

[31] Phillips, S., "There are no invalids in the USSR!": A missing Soviet chapter in the new disability history," Disability Studies Quarterly, 29 (3), 2009. [Online]. Available: http://dsq-sds.org/

[32] Kolupayeva, A., "Trends in the integration of special education in Ukraine," Modern Trends of Special Education Development (Canada-Ukraine Experience), Open University-University “Ukraine”, Kyiv, Ukraine-Edmonton, Canada, 142-146, May 2004

[33] Raver, S., "The emergence of inclusion for students with disabilities in Ukraine," International Journal of Special Education, 22 (1), 32-38, 2007.

[34] Kolupayeva, A., "Trends in the integration of special education in Ukraine," Modern Trends of Special Education Development (Canada-Ukraine Experience). Open University-University “Ukraine”, Kyiv, Ukraine-Edmonton, Canada, 142-146, May 2004.

[35] Csanyi, Y., Hoffman, E. F., Keresztessy, A., Willumsen, J., Curriculum and Handbook for Inclusion, Budapest, European Committee, Ministry for Children, Youth and Sports, Ministry of Education, 2004. 